\title{
Analisis Temporal Kebakaran Hutan dan Lahan di Indonesia Tahun 1997 dan 2015 (Studi Kasus Provinsi Riau)
}

\author{
Afid Nurkholis ${ }^{1}$, Amalya Suci W ${ }^{1}$, Ardian Abdillah $^{1}$, Arum Sari Widiastuti ${ }^{1}$, Ayu Dyah Rahma ${ }^{1}$, \\ Deka Ayu Maretya ${ }^{1}$, Gina Aprila Wangge ${ }^{1}$, Yuli Widyaningsih ${ }^{1}$ \\ ${ }^{1}$ Departemen Geografi Lingkungan, Fakultas Geografi, Universitas Gadjah Mada, Yogyakarta \\ Email: afidnurkholis@gmail.com
}

\begin{abstract}
Abstrak
Kebakaran hutan dan lahan (karhutla) terutama pada lahan gambut sering dialami Indonesia. Sepuluh tahun terakhir, Indonesia menempati urutan ketiga dunia dalam hal pencemaran udara akibat pembakaran hutan, di mana sebelumnya menempati urutan ke-25. Karhutla tahun 1997 merupakan yang terparah sepanjang sejarah Indonesia. Sementara itu, karhutla tahun 2015 yang juga cukup parah menunjukkan bahwa Indonesia telah abai terhadap permasalahan ini. Sumatera merupakan pulau yang memiliki lahan gambut terluas di Indonesia (6,5 juta ha) dengan sebaran gambut paling banyak berada di Provinsi Riau. Penelitian ini akan menjelaskan faktor penyebab dan dampak karhutla secara temporal pada tahun 1997 dan 2015 dengan studi kasus di Provinsi Riau. Selain itu, rekomendasi penanganan karhutla juga menjadi fokus penelitian ini. Data yang digunakan berupa data sekunder dari studi literatur. Analisis data dilakukan secara deskriptif kualitatif dan kuantitatif. Hasil penelitian menunjukkan bahwa adanya anomali iklim EL Nino yang dibarengi dengan pengeringan lahan gambut dan pembakaran sengaja oleh manusia untuk membuka lahan memicu terjadinya karhutla yang masif. Karhutla tahun 1997 jauh lebih parah dilihat dari luasan areal terbakar, korban jiwa, dan kerugian ekonomi yang ditimbulkan. Rekomendasi solusi permasalahan ini adalah menegakkan dan mempertegas peraturan, konservasi berbasis masyarakat, dan melakukan restorasi gambut. Ketiga solusi tersebut telah mengakomodir 3 elemen penting, yaitu pemerintah, masyarakat, dan korporat.
\end{abstract}

Katakunci: gambut, kebakaran hutan, kebakaran lahan, solusi kabakaran hutan-lahan, analisis temporal

\section{$\underline{\text { Sitasi model APA }}$}

Nurkholis, A., Rahma, A. D., Widyaningsih, Y., Maretya, D. A., Wangge, G. A.,... Abdillah, A. (2016, June 16). Analisis Temporal Kebakaran Hutan dan Lahan di Indonesia Tahun 1997 dan 2015 (Studi Kasus Provinsi Riau). http://doi.org/10.17605/OSF.IO/CMZUF 


\section{Pendahuluan}

\subsection{Latar Belakang}

Kebakaran hutan dan lahan terutama pada lahan gambut sering dialami Indonesia. Sepuluh tahun terakhir, Indonesia menempati urutan ketiga dunia dalam hal pencemaran udara akibat pembakaran hutan, di mana sebelumnya menempati urutan ke-25. Menurut United Nations Environment Programme (UNEP) posisi pertama dan kedua ditempati Brasil dan Kongo. Indonesia mengalami deforestasi dengan jumlah penyusutan hutan mencapai 1,1 juta ha (2\% per tahun) dari luas total 130 juta ha akibat kebakaran hutan (Zufrizal, 2015). Kebakaran hutan dan lahan menimbulkan kerugian secara materiil maupun non materiil. Kebakaran hutan terakhir di Indonesia terjadi pada September 2015. Pemerintah dalam menangani kebakaran hutan masih dirasa belum memiliki resolusi kebijakan jangka panjang untuk menangani kebakaran yang hampir setiap tahun terjadi. Penanggulangan kebakaran yang ada masih berkutat seputar teknis pencegahan dan pemadaman kebakaran.

Kasus kebakaran hutan di Indonesia merupakan masalah struktural pengelolaan sumberdaya alam yang hanya dapat diselesaikan dengan pendekatan skema kebijakan, hukum, dan kelembagaan secara progresif. Anggaran mencapai Rp385milliar yang disiapkan pemerintah tahun ini hanya dapat dibenarkan sebatas untuk menyelamatkan dan meminimalisir dampak lingkungan yang akan terjadi. Akan tetapi, tanpa ada intervensi di level kebijakan, hukum, dan kelembagaan, masalah kebakaran di Indonesia tidak akan pernah selesai secara permanen (Baskoro, 2015). Oleh karena itu perlu dilakukan penelaahan bagi akademisi mengenai kebakaran hutan. Perlu adanya analisis mengenai faktor-faktor penyebab kebakaran hutan dan lahan serta membandingkan dampak kejadian kebakaran hutan dari beberapa contoh studi kasus. Selanjutnya akademisi memberikan solusi inovatif dalam penanggulan masalah kebakaran hutan dan lahan gambut dalam berbagai aspek.

\subsection{Tujuan}

Tujuan dari penulisan ini adalah sebagai berikut.

1. Menganalisis faktor-faktor penyebab kebakaran hutan dan lahan tahun 1997 dan 2015 di Indonesia.

2. Menganalisis perbandingan dampak kebakaran hutan dan lahan tahun 2015 dan 1997.

3. Memberikan solusi mengenai permasalahan kebakaran hutan dan lahan.

\section{Kajian Pustaka}

\subsection{Kebakaran Hutan dan Lahan}

Kebakaran hutan merupakan salah satu permasalahan lingkungan yang sering sekali terjadi dan dianggap penting sehingga menjadi perhatian lokal maupun global. (Cahyono, dkk, 2015). Kebakaran hutan menurut Surat Keputusan Menteri Kehutanan No.195/ KptsII/1996 didefinisikan sebagai keadaan di mana hutan dilanda api sehingga mengakibatkan kerusakan hutan dan hasil hutan yang menimbulkan kerugian ekonomi dan lingkungannya (Rasyid, 2014). Berdasarkan sumber penyebabnya, kebakaran hutan dapat dikelompokkan 
menjadi 2, yaitu kebakaran hutan yang terjadi secara alami dan kebakaran hutan yang terjadi akibat ulah manusia.

Lahan (land) merupakan suatu wilayah di permukaan bumi, mencakup semua komponen biosfer yang dapat dianggap tetap atau bersifaat siklis yang berada di atas dan di bawah wilayah tersebut, termasuk atmosfer, tanah, batuan induk, relief, hidrologi, tumbuhan, dan hewan, serta segala akibat yang ditimbulkan oleh aktivitas manusia di masa lalu dan sekarang yang kesemuanya berpengaruh terhadap penggunaan lahan oleh manusia pada saat sekarang dan di masa mendatang (Brinkman dan Smyth, 1973; Vink, 1975; dan FAO, 1976).

\subsection{Gambut}

Menurut Eero Paavilainen dan Juhani Paivanen (1995) dalam Peatland Forestry: Ecology dan Principles, lahan gambut adalah bentanglahan tersusun oleh tanah hasil dekomposisi tidak sempurna dari vegetasi pepohonan tergenang air sehingga kondisinya anaerobik (tanpa oksigen). Gambut terbentuk dari timbunan sisa tanaman yang telah mati. Timbunan terus bertambah karena proses dekomposisi terhambat oleh kondisi anaerob dan/atau kondisi lingkungan lain yang menyebabkan perkembangan biota pengurai rendah. Pembentukan tanah gambut merupakan proses geogenik yaitu pembentukan tanah oleh proses deposisi dan tranportasi, berbeda dengan proses pembentukan tanah mineral umumnya merupakan proses pedogenik (Hardjowigeno, 1987).

Berdasarkan Gambar 1, proses pembentukan gambut dimulai dari adanya pendangkalan danau yang secara perlahan ditumbuhi oleh tanaman air dan vegetasi lahan basah (Noor, 2001). Tanaman secara bertahap membentuk lapisan-lapisan gambut, sehingga danau tersebut menjadi penuh (Gambar 1a dan 1b). Bagian gambut yang mengisi danau dangkal dikenal sebagai gambut topogen, karena proses yang disebabkan topografi daerah cekungan. Gambut topogen relatif subur (eutrofik) karena pengaruh tanah mineral. Tanaman yang tumbuh dan mati di atas gambut topogen akan membentuk lapisan gambut baru yang membentuk dome gambut berbentuk cembung (Gambar 1c). Gambut ombrogen mempunyai kesuburan lebih rendah dibandingkan dengan gambut topogen karena hampir tidak ada pengkayaan mineral.

Lahan gambut di Indonesia terdapat di dataran rendah dan dataran tinggi (Gambar 2). Pada umumnya, lahan rawa gambut di dataran rendah terdapat di kawasan rawa pasang surut dan rawa pelembahan, terletak di antara dua sungai besar pada fisiografi backswamp, swalle, closed basin, dan coastal plain. Lahan rawa gambut di dataran tinggi umumnya terdapat di cekungan seperti di Rawa Pening (Jawa Tengah), Padang Sidempuan (Sumatera Utara), dan Danau Sentanu, Kapuas Hulu (Kalimantan Barat). Sebagian besar lahan rawa gambut terdapat di dataran rendah dan hanya sebagian kecil yang terdapat di dataran tinggi (Subagyo, 1988).

Balai Besar Litbang Sumberdaya Lahan Pertanian menyusun peta gambut untuk mendukung Peta Indikasi Penundaan Ijin Baru (PIPIB) hutan alam primer dan lahan gambut dengan masukan hasil survei pemetaan tanah yang dilakukan oleh Kementerian Pertanian sampai dengan tahun 2010. Hasilnya luas gambut di 3 pulau besar yaitu Sumatera, 
Kalimantan, dan Papua sekitar 14,9 juta ha. Hal tersebut karena di 3 pulau tersebut curah hujan lebih tinggi daripada Jawa dan Sulawesi. Selain itu daerahnya datar. Kombinasi dari curah hujan tinggi dan lahan relatif datar akan menghasilkan banyak lahan terendam air. Lahan terendam air yang berpotensi membentuk ekosistem rawa gambut. Peta diperbaharui setiap 6 bulan sekali sesuai dengan mekanisme PIPIB antara lain menghimpun masukan/klaim perusahaan konsesi perkebunan, dan hasil pemetaan tanah semi detil yang dilakukan oleh BBSDLP (Inpres No.6/2013).

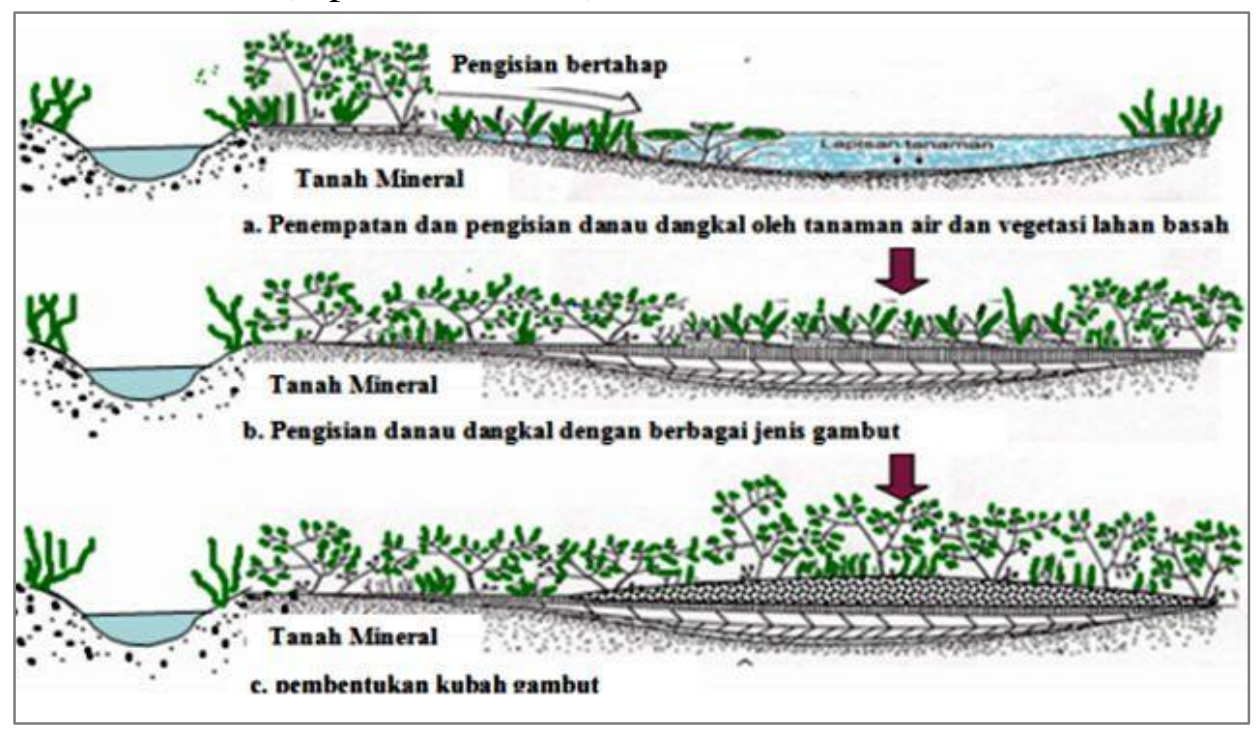

Gambar 1. Proses Pembentukan Lahan Gambut (Noor, 2011)

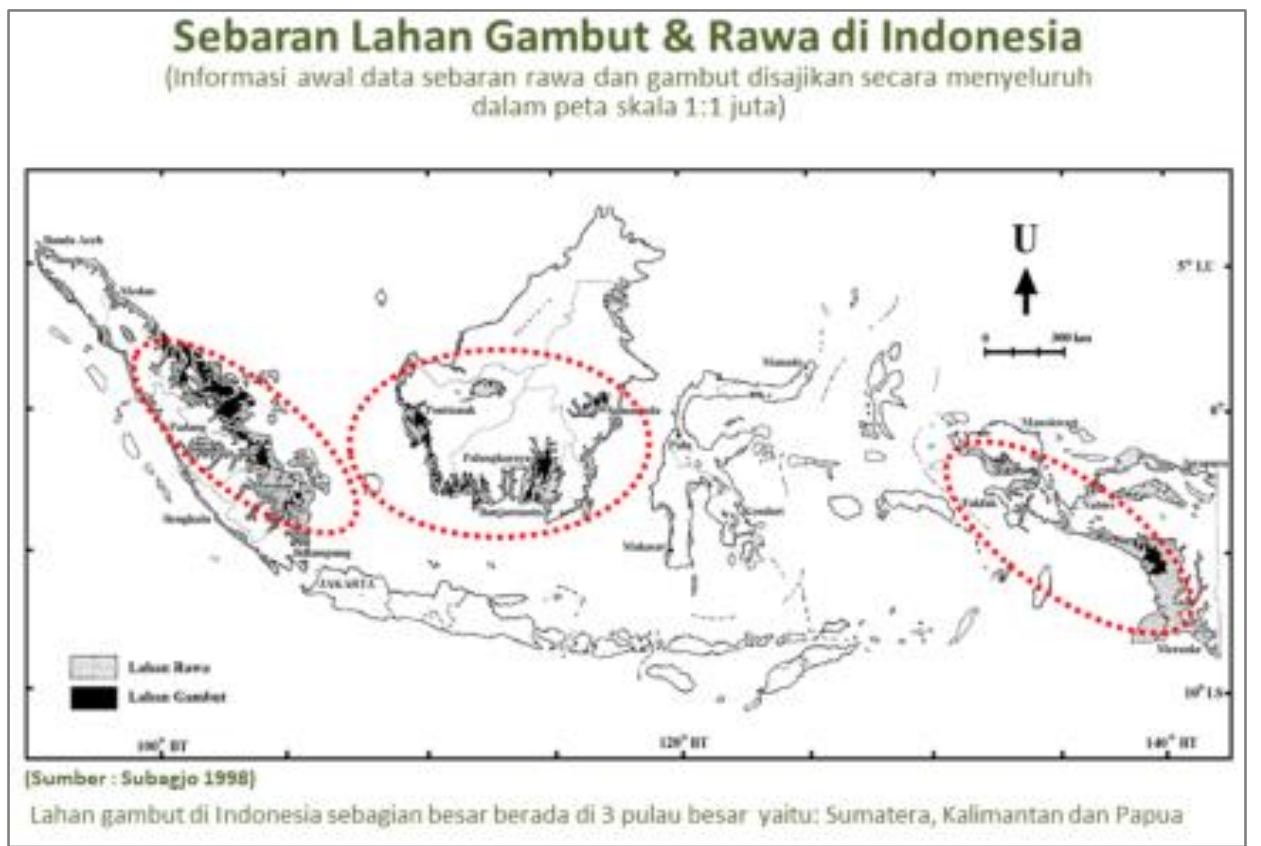

Gambar 2. Peta Lahan Gambut (Wetland International dalam Inpres No.6, 2013) 


\subsection{Proses Kebakaran Hutan}

Kebakaran dapat terjadi jika tersedia oksigen, sumber penyulut, bahan bakar menghasilkan karbondioksida, panas, dan partikel koloid lain. Proses pembakaran adalah kebalikan proses fotosintesis. Reaksi kimia dari proses pembakaran adalah sebagai berikut:

\begin{tabular}{l}
\hline $\begin{array}{l}\text { Proses pembakaran: } \\
\left(\mathrm{C}_{6} \mathrm{H}_{10} \mathrm{O}_{6}\right) \mathrm{n}+\mathrm{O}_{2}+\text { panas penyalaan } \longrightarrow \mathrm{CO}_{2}+\mathrm{H}_{2} \mathrm{O}+\text { panas } \\
\text { (Bahan bakar) (oksigen) (panas/sumber penyulut) }\end{array}$ \\
\hline
\end{tabular}

Berkaitan dengan hal tersebut, kejadian kebakaran hutan dan lahan gambut yang sering terjadi disebabkan karena terdapatnya sumber penyulut dan bahan bakar di alam. Sumber penyulut kebakaran hutan ini adalah adanya perubahan karakteristik kependudukan yang memicu terjadinya pembakaran lahan secara sengaja untuk dimanfaatkan dalam berbagai kepentingan. Kebakaran di bagian permukaan pada lahan gambut memiliki kecepatan yang sangat tinggi yaitu sebesar 502,5 kg/m² (Akbar dkk, tanpa tahun).

Kebakaran lahan gambut dapat terjadi dengan mudah ketika lahan gambut berada dalam kondisi kering. Lahan gambut dapat kering secara alami ataupun karena dikeringkan dengan cara pembuatan kanal-kanal yang mengalirkan air dari rawa gambut ke sungai. Kebakaran lahan gambut yang terjadi secara alami tidak berbahaya dan terjadi pada musim kemarau dengan dampak kebakaran yang sangat kecil. Kebakaran hutan yang terjadi secara alami bahkan dapat memberikan dampak yang positif karena dapat mengurangi spesies keanekaragaman hayati yang terlalu dominan sehingga terjadi keseimbangan ekosistem di hutan atau lahan gambut.

Berdasarkan tipe, kebakaran hutan dan lahan dikelompokkan menjadi 3 tipe (Gambar 3). Kebakaran bawah (ground fire) adalah kebakaran pada bagian bawah permukaan tepatnya pada lapisan organik. Kebakaran permukaan (surface fire) yaitu kebakaran yang terjadi di permukaan yang membakar seresah, semak belukar, pancang, dan limbah pembalakan. Kebakaran tajuk (crown fire) adalah kebakaran yang terjadi pada pucuk-pucuk pohon.

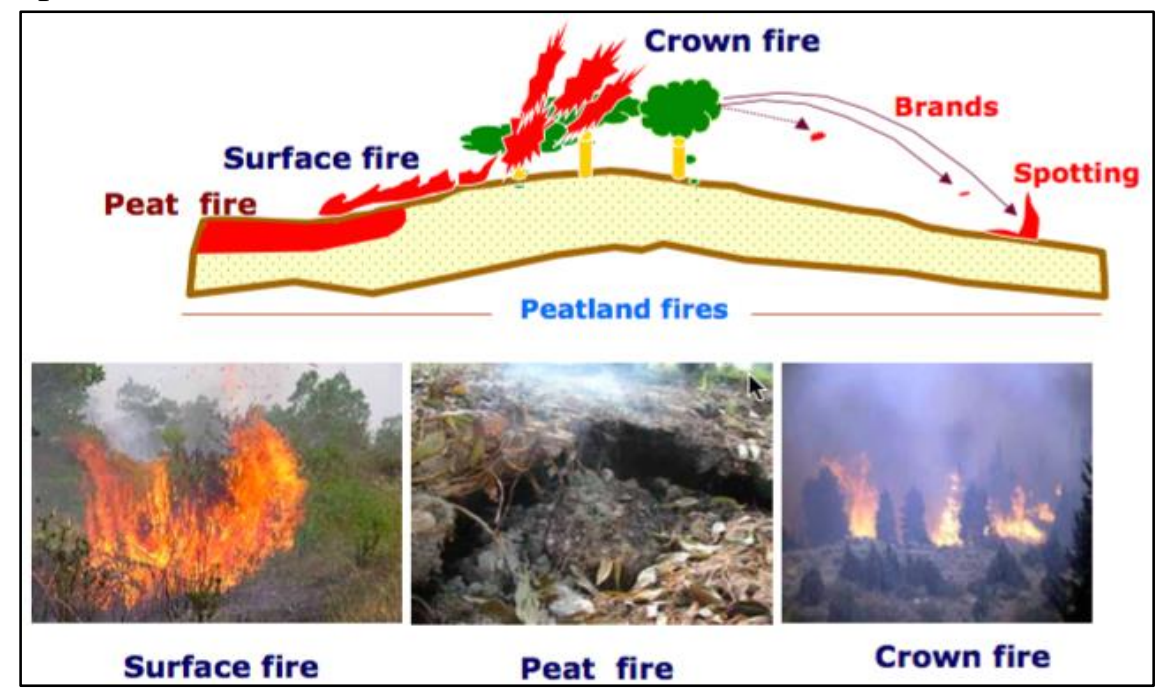

Gambar 3. Tipe Kebakaran Hutan dan Lahan (Usup et al, 2004) 
Proses kebakaran lahan gambut diawali adanya penyulutan api yang menyebabkan api bergerak ke segala arah. Kebakaran yang terjadi di bagian permukaan sangat dipengaruhi oleh arah dan kecepatan angin. Jika kecepatan angin tinggi maka kebakaran yang terjadi juga akan semakin besar dan dapat memicu kebakaran tajuk. Bagian dari pohon yang terbakar dapat diterbangkan angin dan jatuh ke tempat baru sehingga memicu kebakaran di lokasi lain. Semakin rendah kadar air pada gambut maka akan semakin cepat laju pembakarannya. Kebakaran gambut masih bisa terjadi pada kadar air 119\% yang merupakan kadar air kritis kebakaran gambut. Tingkat dekomposisi gambut juga mempengaruhi keterbakaran gambut, semakin matang gambut (jenis saprik) semakin sulit terbakar dibandingkan dengan jenis gambut yang belum matang (jenis fibrik dan hemik). Tinggi muka air akan mempengaruhi kadar air gambut, sementara curah hujan mempengaruhi tinggi muka air lahan gambut (Saharjo dan Syaufina, 2004).

\section{Metode Penelitian}

Metode yang digunakan yaitu teknik pengambilan data dan teknik analisis data yang diterapkan pada suatu lokasi kajian dengan penjelasan sebagai berikut.

\subsection{Teknik Pengambilan Data}

Data yang digunakan di penelitian berupa data sekunder dari studi literatur. Pengambilan data dilakukan dengan mengambil beberapa informasi mengenai kejadian kebakaran hutan dan lahan secara temporal. Data temporal kejadian kebakaran hutan dan lahan yang diambil adalah data tahun 1997 dan 2015. Tahun tersebut diambil berdasarkan data kejadian kebakaran hutan dan lahan terparah.

\subsection{Teknik Analisis Data}

Analisis data dilakukan secara deskriptif kualitatif dan kuantitatif. Analisis secara deskriptif kualitatif dilakukan dengan cara mendeskripsikan karakteristik mengenai kebakaran hutan dan lahan. Deskripsi tersebut dilakukan dengan membandingkan beberapa studi literatur untuk mengetahui informasi dan perbedaan spasial sebaran lahan gambut yang ada di Indonesia. Deskripsi kualitatif juga digunakan untuk mengetahui faktor penyebab kebakaran hutan dan lahan. Analisis secara deskriptif kuantitatif digunakan untuk mengetahui data kerugian. Deskripsi kuantitatif dilakukan dengan cara mencari data besaran kerugian pada contoh kasus kebakaran hutan dan lahan yang terjadi pada tahun 1997/ 1998 dan 2015. Besaran angka yang ditimbulkan oleh kebakaran lahan dan hutan pada kedua tahun tersebut kemudian dibandingkan.

\subsection{Lokasi Kajian}

Provinsi Riau merupakan salah satu provinsi di Sumatera yang terletak pada $01^{\circ} 05^{\prime} 00^{\prime \prime}$ LS - $02^{\circ} 25^{\prime} 00^{\prime \prime}$ LU dan $100^{\circ} 00^{\prime} 00^{\prime \prime}$ BT - $105^{\circ} 05^{\prime} 00^{\prime \prime}$ BT di sebelah timur Pulau Sumatera. Provinsi Riau yang memiliki luas daerah 9,4 juta ha sekitar $40 \%$ ( 3,9 juta ha) berupa dataran rendah bergambut dan sebagian diantaranya dipengaruhi oleh pasang surut. Keberadaan lahan gambut di Riau didukung oleh kondisi topografi landai dan iklim dengan 
curah hujan 1700-4000 mm/tahun. Lahan gambut di Riau merupakan salah satu provinsi dengan luas lahan gambut terluas di Sumatera. Hal ini didasarkan pada data yang diambil oleh Badan Lingkungan Hidup Provinsi Riau. Kedalaman lahan gambut yang terdapat di provinsi ini mencapai $50 \mathrm{~cm}$ sampai lebih dari $300 \mathrm{~cm}$. Provinsi Riau yang selama 2 dekade terakhir telah mengalami eksploitasi sumberdaya hutan secara besar-besaran. Provinsi ini telah mengubah tata guna lahan dari kawasan hutan yang utuh menjadi kawasan perkebunan dan transmigrasi terutama pada lahan kering dan pasang surut dengan luasan mencapai lebih dari 2 juta ha. Hal ini menyebabkan pada lima tahun terakhir investor di bidang perkebunan dan HTI mengarah ke lahan basah atau lahan gambut. Kondisi lahan di Provinsi Riau menurut DDA tahun 2015, lahan basah lebih mendominasi di Provinsi Riau. Dalam proses pembukaan lahannya untuk perkebunan dan HTI menggunakan metode yang murah dan efektif dengan cara membakar. Hal ini menyebabkan potensi kebakaran hutan di Provnsi Riau besar. Kasus kebakaran hutan di Provinsi Riau terparah terjadi pada tahun 1997-1998 yang merupakan kasus kebakaran hutan terparah di Indonesia hingga saat ini. Kemudian kasus kebakaran hutan sering terjadi di Provinsi Riau sampai tahun 2015 terjadi kebakarann hutan dan lahan yang menyebabkan kerugian materiil dan non materiil.

\section{Hasil dan Pembahasan}

\subsection{Kebakaran hutan terparah sepanjang sejarah yang terjadi di Riau Indonesia di tahun 1997/1998.}

Sebesar 40\% luas daratan Provinsi Riau 9,4 juta ha merupakan lahan gambut (3,9 juta ha) dan sebagian merupakan lahan yang dipengaruhi oleh pasang surut. Kejadian kebakaan terbesar di Provinsi Riau terjadi pada tahun 1997-1998 (Gambar 4). Selanjutnya setiap musim kering terjadi kebakaran di Provinsi Riau, namun tidak separah di tahun 19971998. Terbatasnya lahan kering d Provinsi Riau akibat alih fungsi lahan dan kegiatan transmigrasi menyebabkan para investor perkebunan dan HTI mulai mengarah ke lahan basah (bergambut). Kebakaran yang terjadi pada tahun 1997-1998 akibat pengeringan (Land Clearing) mencapai 26.000 ha (Darjono,2003). Kebakaran pada tahun 1997-1998 juga dipicu dengan adanya fenomena El-Nino terparah sepanjang tahun.

Terjadi kebakaran serta dampaknya pada bulan September 1997 hingga bulan Mei 1998. Luasan area terbakar mencapai 51.255 ha, terdiri dari HPH 6.737 ha, HPHTI 4.953 ha, perkebunan 28.133 ha, penggunaan lain 11.431 ha. Akibat adanya kebakaran pada tahun 1997 Indonesia menghasilkan emisi CO2 sebesar 0.81--2.5 Giga Ton. Nilai tersebut mendekati $13--40 \%$ total emisi CO2 per tahun di dunia. Selain hal tersebut Indonesia terpajan oleh asap. Berikut merupakan distribusi kabut asap akibat kebakaran tahun 19971998.

Berdasarkan Gambar 4, negara tetangga seperti Malaysia, Singapura dan sebagian Australia mendapatkan dampak kabut asap kebakaran di Indonesia. Adanya kabut asap menyebabkan jarak pandang hanya mencapai 10-30 meter. Kabut asap menimbulkan gangguan kesehatan bagi masyarakat, terganggunya aktivitas transportasi darat dan udara, 
terganggunya kestabilan politik dengan negara tetangga, dan terhentinya aktivitas ekonomi. Kerugian akibat adanya kebakaran dilansir mencapai 4,4 Milyar US\$ (WWF) dan sebanyak 20 juta orang terpajan gangguan pernapasan (WHO). Tabel 1 menunjukan dampak kesehatan akibat kabut yang terkait dengan kebakaran hutan.

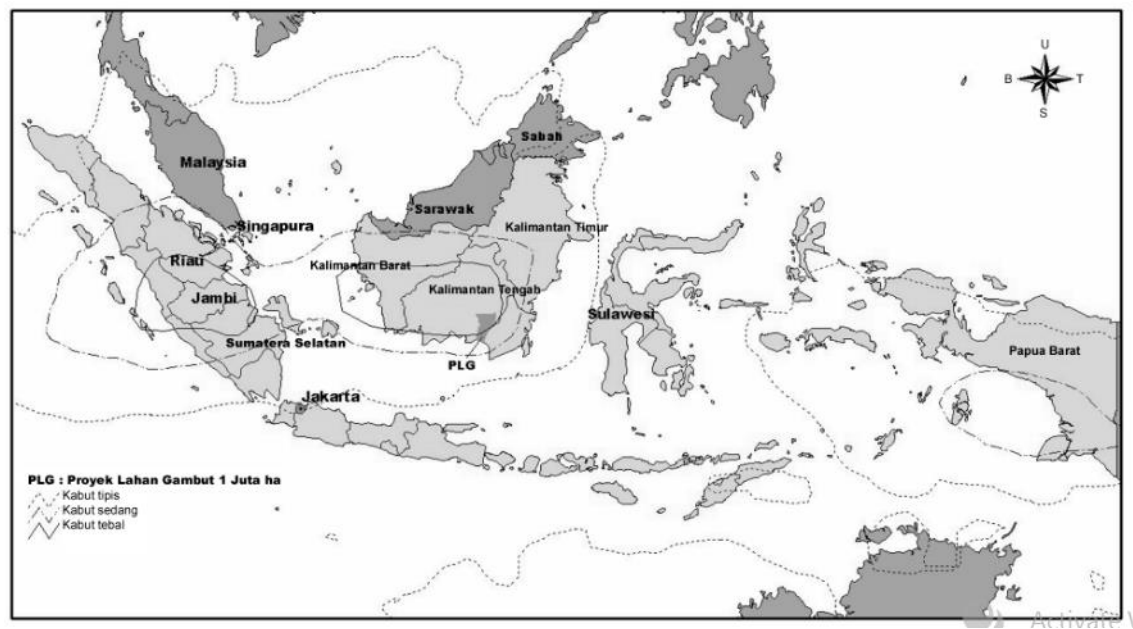

Gambar 4. Peta Persebaran Kabut Asap Akibat Kebakaran Hutan Tahun 1997-1998 (Barber dan Schwelthelm (2000) dalam Tacconi, 2003)

Tabel 1. Dampak Kesehatan Akibat Kabut yang Terkait dengan Kebakaran Hutan di 8 Provinsi di Indonesia, September-November 1997.

\begin{tabular}{l|r}
\hline Dampak kesehatan & \multicolumn{1}{|c}{ Jumlah kasus } \\
\hline Kematian & 527 \\
Asma & 298.125 \\
Bronkitis & 58.095 \\
Infeksi saluran napas akut & 1.446 .120 \\
Kendala melakukan kegiatan setiap hari & 4.758 .600 \\
Peningkatan perawatan pasien rawat jalan & 36.462 \\
Peningkatan perawatan pasien rawat inap & 15.822 \\
Kehilangan hari kerja & 2.446 .352 \\
\hline
\end{tabular}

\subsection{Kebakaran hutan Riau yang terjadi di Indonesia di tahun 2015.}

Kebakaran hutan ini terjadi pada bulan September-November 2015. Sama halnya di tahun 1997, kebakaran kali ini disebabkan oleh adanya anomali iklim yaitu fenomena El-Nino di Samudera Pasifik yang menyebabkan terjadinya kekeringan di Indonesia. Kebakaran hutan yang terjadi di Riau tahun 2015 dipicu pula oleh pembukaan lahan yang dilakukan oleh perusahan-perusahaan dengan cara dibakar. Berdasarkan hasil kajian Eyes on The Forest terdapat 37 perusahaan termasuk kebun kelapa sawit, HPH dana HTI yang dilakukan cek lapangan dan diduga yang membakar hutan di titik-titik api. Berdasarkan pada temuan lapangan, EoF menduga terjadi 
pembakaran hutan dan lahan secara sengaja maupun pembiaran dengan motif-motif yang masih perlu diselidiki lebih lanjut oleh aparat penegak hukum. Pengecekan lapangan menunjukkan estimasi wilayah yang terbakar di 38 konsesi seluas 7.578 hektar. Konsesi HTI merupakan kelompok terbanyak memiliki titik panas/api selama kurun ini berdasarkan izin usaha. Hal ini ditunjukkan dengan peta rekapitulasi titik panas/api yang terekam dari Juli-Oktober 2015 di Riau berdasarkan klasifikasi izin per bulan di mana bulan Juli terbanyak titik panas/api dan kelompok HTI terbanyak di kelompok izin (Gambar 5).

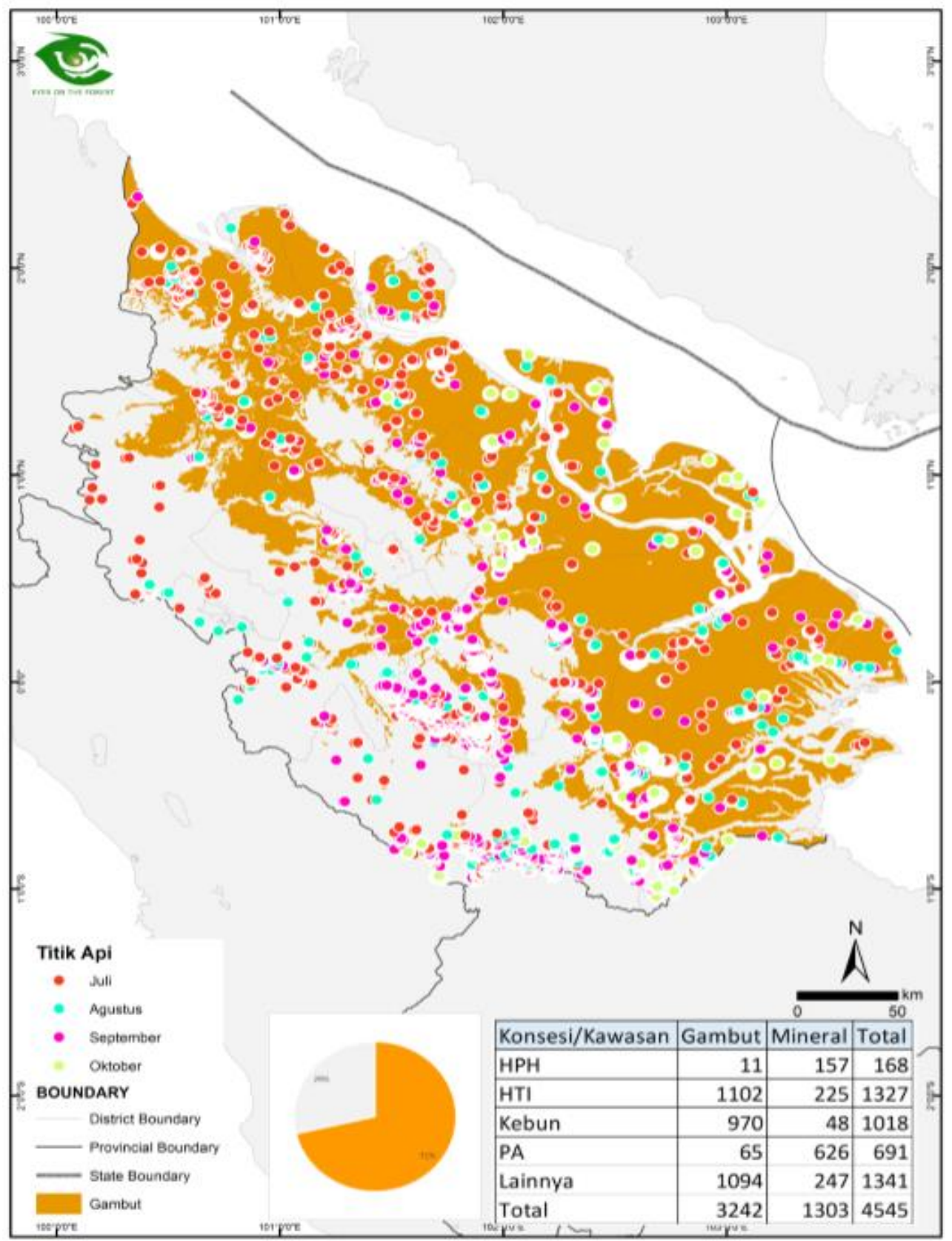

Gambar 5. Peta Rekapitulasi Titik Api yang Terekam dari Juli-Oktober 2015 di Riau (Eyes on The Forest, 2015) 
Akibat terjadinya kebakaran hutan di Riau tahun 2015 menyebabkan lahan terbakar seluas 2.643 ha (KLHK,2016). Besar kerugian yang ditaksir mencapai lebih dari Rp 20 Triliun. Dampak lainnya yang ditimbulkan yaitu adanya kabut asap. Tabel 2 merupakan provinsi yang terkena dampak akibat kebakaran hutan dan lahan.

Tabel 2. Jumlah Kabupaten/Kota Terdampak Kabut Asap Per 23 November 2015

\begin{tabular}{|c|c|c|}
\hline Pulau & Provinsi & Kab/Kota \\
\hline \multirow{9}{*}{ Sumatera } & Riau & $12 \mathrm{kab} / \mathrm{kota}$ \\
\hline & lambi & $6 \mathrm{kab} / \mathrm{kota}$ \\
\hline & Sumatera Selatan & 8kab/kota \\
\hline & Bengkulu & 9 kab/kota \\
\hline & Aceh & $9 \mathrm{kab} / \mathrm{kota}$ \\
\hline & Kepulauan Riau & 4 kab/kota \\
\hline & Bangka Belitung & 3 kab/kota \\
\hline & Sumatera Utara & $5 \mathrm{kab} / \mathrm{kota}$ \\
\hline & Sumatera Barat & 9 kab/kota \\
\hline \multirow{5}{*}{ Kalimantan } & Kalimantan Tengah & 12 kab/kota \\
\hline & Kalimantan Barat & 9 kab/kota \\
\hline & Kalimantan Selatan & II kab/kota \\
\hline & Kalimantan Utara & $2 \mathrm{kab} / \mathrm{kota}$ \\
\hline & Kalimantan Timur & 4 kab/kota \\
\hline \multirow{2}{*}{ Papua \& Papua Barat } & Papua & $4 \mathrm{kab} /$ kota \\
\hline & Papua Barat & 5 kab/kota \\
\hline
\end{tabular}

Sumber: Pusat Penanggulangan Krisis Kesehatan, Kementrian Kesehatan, 2015.

Asap yang ditimbulkan akibat kebakaran tersebut mengakibatkan jarak pandang hanya sekitar 200-500 meter (BLH JOGJA, 2016). Kabut asap juga menyebabkan terganggunya transportasi darat, udara, dan laut serta kestabilan politik dengan negara tetangga. Gangguan kesehatan ISPA terjadi akibat masyarakat yang terpajan oleh kabut asap. Gambar 6 menunjukkan jumlah kasus ISPA akibat asap.

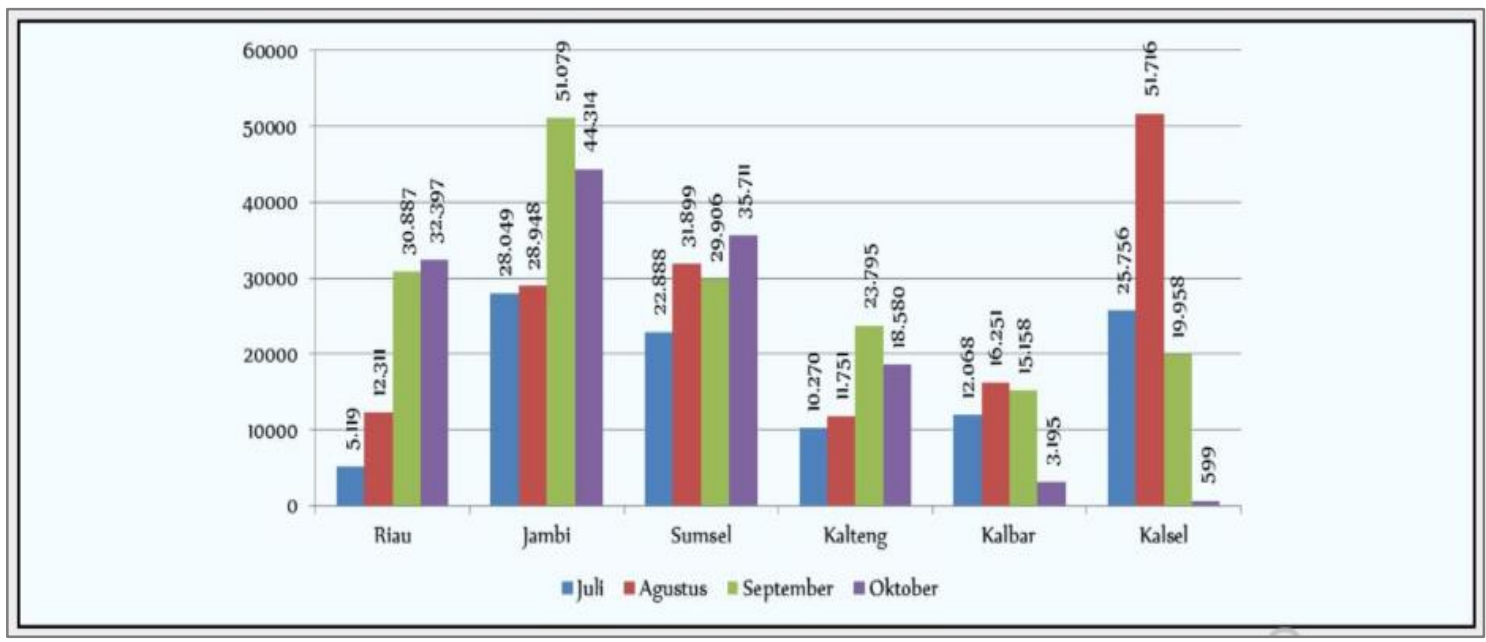

Gambar 6. Jumlah Kasus ISPA Periode Juli-September 2015

(Dinas Kesehatan Provinsi, melalui PPKK Kemenkes RI) 
Besar emisi karbon yang dihasilkan mencapai 1 milyar ton, di mana setiap harinya memancarkan emisi sebsar 15-20 juta ton. Emisi ini lebih besar dibandingkan dengan emisi karbon yang dikeluarkan oleh Jerman dan Amerika Serikat dalam setahun yaitu 14 juta ton per hari (Hasil penelitian Guido van Der Werf, peneliti dari Universitas Amsterdam). Gambar 7 menunjukkan Indeks Standar Pencemaran Udara (ISPU).

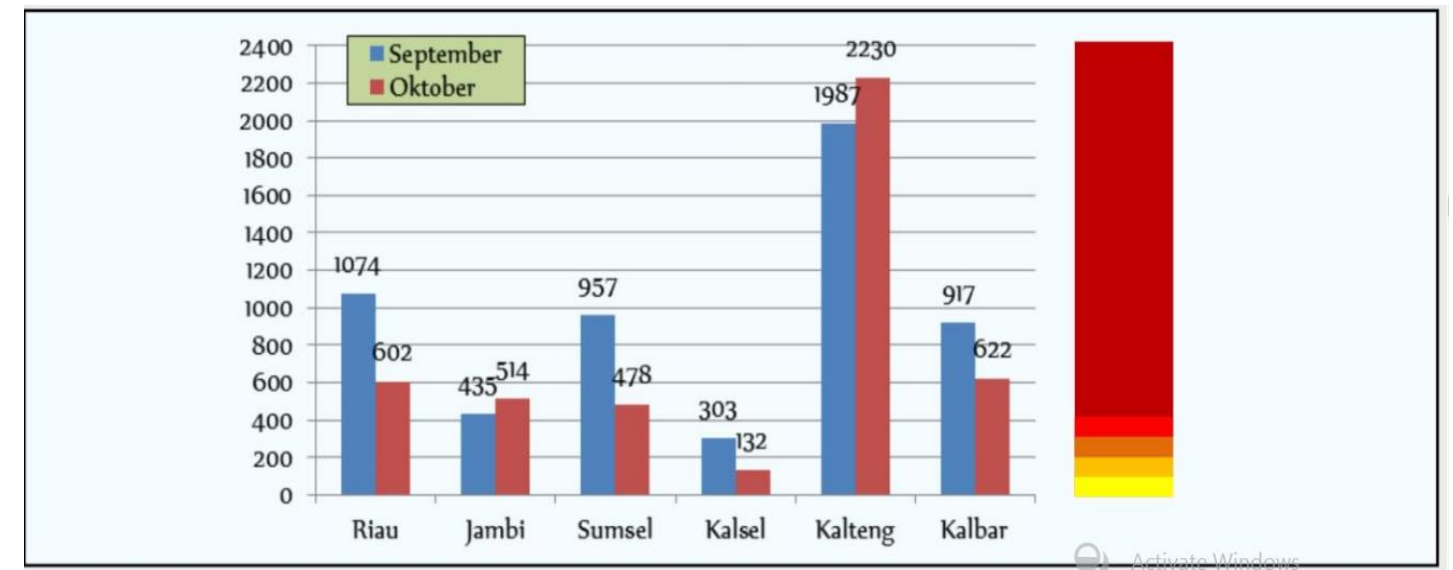

Gambar 7. ISPU Tertinggi di 6 Provinsi Terdampak Kebakaran Hutan dan Lahan 2015 (Pantauan PPKK Kemenkes terhadap Pusat Data Karhutla, Pusdatin Kemenkes RI)

\subsection{Upaya Konservasi}

Situs berita sains.kompas.com menyatakan bahwa hasil pengumpulan data kebakaran hutan dan lahan di Indonesia sejak tahun 1960 - 2015 menunjukkan tren yang semakin meningkat. Hal ini memiliki arti bahwa pemerintah telah abai selama empat dekade terakhir. Oleh karena itu, langkah-langkah serius perlu dilakukan untuk mencegah terulangnya kesalahan yang sama. Konservasi pencegahan kebakaran merupakan tindakan yang lebih penting daripada mencoba memadamkan api. Upaya konservasi jangka panjang untuk mencegah terjadinya kebakaran hutan dan lahan dapat diupayakan sebagai berikut.

\section{Menegakkan dan Mempertegas Peraturan}

Pemerintah pada dasarnya telah memberi perhatian dalam permasalahan kebakaran hutan dan lahan khususnya di ekosistem gambut. Hal ini ditunjukkan dengan adanya peraturan-peraturan yang telah mengatur pemanfaatan ekosistem gambut, seperti: a) Undang-undang Nomor 32 Tahun 2009 mengenai "Perlindungan dan Pengelolaan Lingkungan Hidup".

b) Peraturan Pemerintah Nomor 71 Tahun 2014 mengenai "Perlindungan dan Pengelolaan Ekosistem Gambut.

c) Peraturan Menteri Pertanian Nomor 14 Tahun 2009 mengenai "Pedoman Pemanfaatan Lahan Gambut untuk Budidaya Kelapa Sawit".

Ketiga peraturan tersebut sudah cukup jelas mengatur mengenai pentingnya menjaga kelestarian ekosistem gambut, namun pada kenyataannya terdapat dua hal yang menjadi kelemahan, yaitu peraturan yang kurang jelas (pasal karet) dan pelanggaran yang 
kurang mendapat sangki tegas. Adanya pasal karet ditunjukkan dalam UU 32 Tahun 2009 yang berisi seperti berikut ini.

Ayat (2)

Kearifan lokal yang dimaksud dalam ketentuan ini adalah melakukan pembakaran lahan dengan luas lahan maksimal 2 hektare per kepala keluarga untuk ditanami tanaman jenis varietas lokal dan dikelilingi oleh sekat bakar sebagai pencegah penjalaran api ke wilayah sekelilingnya.

Isi peraturan tersebut memungkinkan seseorang/ kelompok usaha untuk melakukan pembakaran hutan dalam pembukaan lahan.

Kurang tegasnya sanksi terhadap pelanggaran yang dilakukan ditunjukkan dengan masih minimnya pencekalan terhadap pelaku pembakar hutan hingga ke akar. Seringkali pelaku pembakar yang ditangkap hanyalah orang dilapangan tanpa bisa menunjukkan aktor utama dari kejahatan ini. Menurut Herry Purnomo, peneliti dari Center for International Forestry Research (CIFOR), hal ini diakibakan oleh pelaku pembakaran hutan yang terorganisir kuat dan memiliki koneksi pejabat dari mulai daerah hingga ke pusat (www.bbc.com).

\section{Restorasi Gambut}

Kebakaran hutan dan lahan yang telah reda akan menyisakan ekosistem gambut yang telah rusak. Menurut KLHK (2015), hal pertama yang harus dilakukan dalam restorasi gambut adalah melakukan restorasi tata air. Hal ini dikarenakan faktor utama terbentuknya ekosistem gambut adalah adanya genangan air. Selain itu, penyebab utama kebakaran di lahan ini adalah dikeringkannya air. Langkah restorasi tata air dapat dilakukan dengan berbagai cara, seperti: penutupan kanal, pembendungan sungai, memompa air ke lahan gambut (KLHK, 2015). Apabila lahan gambut telah dilakukan tata airnya, langkah selanjutnya adalah melakukan restorasi vegetasi. Pedoman melakukan restorasi vegetasi dapat dilakukan seperti yang dijelaskan pada Tabel 3.

Tabel 3. Pedoman Restorasi Vegetasi

\begin{tabular}{|c|l|l|}
\hline No. & \multicolumn{1}{|c|}{ Kondisi Lokasi } & \multicolumn{1}{c|}{ Alternatif Jenis Tanaman } \\
\hline 1 & Areal yang: & - Jelutung rawa (Dyera polyphilla) \\
& > Bekas terbakar ringan/sedang & - Perepat (Combretocarpus rotundatus) \\
& - Bekas tebang habis & - Belangiran (Shorea belangeran) \\
& > Areal terbuka (vegetasi jarang) & - Pulai rawa (Alstonia pneumatophora) \\
& & - Rengas manuk (Syaygium Sp) \\
& & - Terentang (Campnosperma Coriacea)
\end{tabular}




\begin{tabular}{|c|c|c|}
\hline No. & Kondisi Lokasi & Alternatif Jenis Tanaman \\
\hline 2 & $\begin{array}{l}\text { Areal yang: } \\
\text { > Bekas terbakar yang telah mengalami } \\
\text { suksesi } \\
\text { > Bekas tebang selektif } \\
>\text { Penutupan vegetasi sedang }\end{array}$ & $\begin{array}{l}\text { - Meranti rawa (Shorea pauciflora, } \\
\quad \text { uliginosa) } \\
\text { - Merapat (Combretocarpus rotundatus) } \\
\text { - Durian (Durio carinatus) } \\
\text { - Ramin (Gonystylus bancanus) } \\
\text { - Punak (Tetramerista glabra) } \\
\text { - Kempas (Koompassia malaccensis) } \\
\text { - Resak (Vatica rassak) } \\
\text { - Kapur Naga (Calophyllum } \\
\text { - } \text { macrocarpum) } \\
\text { - } \text { Bintan (Palaquium spp.) } \\
\text { - Calaphyllum Hosei) }\end{array}$ \\
\hline 3 & $\begin{array}{l}\text { Areal yang: } \\
\text { > Bekas tebang selektif } \\
\text { > Masih banyak dijumpai pohon } \\
\text { > Penutupan vegetasi masih tinggi } \\
\text { > Telah kehilangan jenis tanaman } \\
\quad \text { komersil (bernilai tinggi) }\end{array}$ & 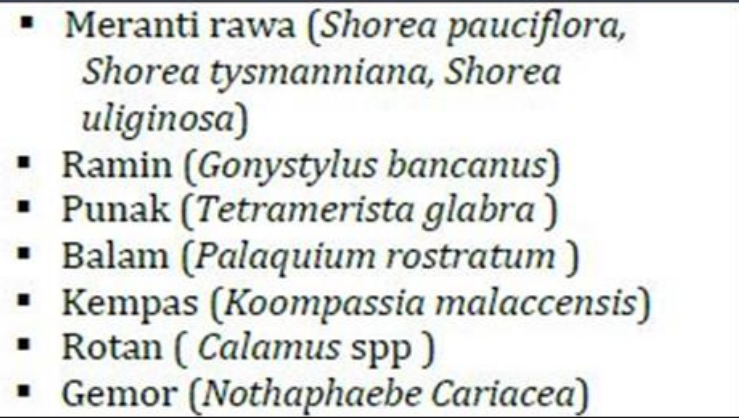 \\
\hline
\end{tabular}

Sumber: BPDAS 2015.

\section{Konservasi Berbasis Masyarakat}

Konservasi berbasis masyarakat merupakan hal yang penting mengingat selama ini beredar kabar masyarakat lokal banyak dimanfaatkan oleh korporat untuk melakukan pembakaran hutan dan lahan. Menurut The Canadian International Development Agency (CIDA) (2016), peran serta masyarakat dalam pencegahan kebakran ini dipengaruih beberapa faktor, seperti dorongan dan rangsangan, insentif, serta bimbingan. Dorongan dan rangsangan masyarakat dapat tercipta mekakui penyuluhan maupun diskusi yang dilakukan secara rutin. Insentif lokal dapat dilakukan dengan mengembangkan produk-produk alternatif yang memiliki nilai ekonomi, seperti hasil kerajinan rotan, budidaya ikan dalam gambut, dan pembuatan kompos. Organisasi masyarakat peduli kebakaran hutan dan lahan dibentuk dengan penanggung jawab kepala desa yang selanjutnya dibimbing oleh LSM dan dinas terkait.

\section{Kesimpulan dan Rekomendasi}

Kesimpulan dari penelitian ini adalah sebagai berikut.

1. Penyebab utama kebakaran hutan dan lahan tahun 1997 dan 2015 di Indonesia adalah pengeringan lahan gambut dan pembakaran sengaja oleh manusia untuk membuka lahan. Lahan gambut yang telah dikeringkan akan memicu kebakaran yang sulit 
dipadamkan akibat kedalaman bahan organik dapat lebih dari 3 meter. Hal ini diperparah dengan adanya anomali iklim EL Nino yang menjadikan kebakaran hutan dan lahan semakin masif.

2. Perbandingan dampak kebakaran hutan dan lahan tahun 2015 dan 1997 bahwa kejadian kebakaran hutan tahun 1997 jauh lebih parah dilihat dari luasan area terbakar sebesar 51.255 hektar, kerugian ekonomi mencapai 4,4 Milyar US\$, gangguan pernapasan yang dialami 20 juta orang, pencemaran lingkungan terutama udara, gangguan transportasi, hingga gangguan stabilitas hubungan politis. Hal tersebut juga menjadikan kebakaran hutan tahun 1997 di Indonesia menjadi sejarah kebakaran terparah yang pernah terjadi.

3. Solusi mengenai permasalahan kebakaran hutan dan lahan yaitu menegakkan dan mempertegas peraturan, konservasi berbasis masyarakat, dan melakukan restorasi gambut. Ketiga solusi tersebut telah mengakomodir 3 elemen penting, yaitu pemerintah, masyarakat, dan korporat.

Rekomendasi dari penelitian ini adalah sebagai berikut:

1. Pemerintah sebagai pemangku kebijakan sudah seharusnya fokus terhadap pencegahan jangka panjang. Pembentukan badan restorsi gambut hanyalah langkah awal. Tindakan nyata di lapangan merupakan wujud keseriusan yang harus segera dilaksanakan.

2. Pengawalan terhadap penanganan karhutla harus melibatkan seluruh elemen masyarakat. Empat elemen penting, yaitu pemerintah, masyarakat sipil, korporat, dan akademisi harus berkontribusi terhadap permasalahan ini.

\section{Daftar Pustaka}

Akbar, A dkk. Tanpa ttahun. Kebakaran Hutan dan Lahan Rawa Gambut: Penyebab Faktor Pendukung dan Alternatif Pengelolaannya. Banjarbaru: Balai Penelitian Kehutanan Banjarbaru.

Anonim. Undang-undang Nomor 32 Tahun 2009 mengenai "Perlindungan dan Pengelolaan Lingkungan Hidup"

Anonim. Peraturan Pemerintah Nomor 71 Tahun 2014 mengenai "Perlindungan dan Pengelolaan Ekosistem Gambut.

Anonim. Peraturan Menteri Pertanian Nomor 14 Tahun 2009 mengenai "Pedoman Pemanfaatan Lahan Gambut untuk Budidaya Kelapa Sawit”.

Brinkman, A.R. dan A. J. Smith, 1973. Land Evaluation for Rural Purposes. ILRI Publ. No. 17 Wageningen. 
Cahyono, S. Andy, Sofyan P. Warsito, Wahyu Andayani, dan Dwidjono H. Darwanto. 2015. Faktor - Faktor yang Mempengaruhi Kebakaran Hutan di Indonesia dan Implikasi Kebijakannya. Jurnal Sylva Lestari, Vol. 3, No. 1. Hal : 103 - 112.

CIDA. 2016. Strategi Pencegahan Kebakaran Hutan dan Lahan Gambut. Brosur Seri Pengelolaan Hutan dan Lahan Gambut.

Danny, W. 2001. Interaksi Ekologi dan Sosial Ekonomi dengan Kebakaran di Hutan Provinsi Kalimantan Timur, Indonesia. Paper Presentasi pada Pusdiklat Kehutanan. Bogor.

Darono. 2003. Pengalaman Penegakan Hukum yang Berkaitan dengan Kebakaran di Areal Perkebunan dan HTI Rawa Gambut. Jakarta: Cifor.

Eyes on The Forest (EoF).2015. Laporan Investigatif Eyes on the Forest Desember 2015. Riau.

Hardjowigeno, S., and Abdullah. 1987. Suitability of peat soils of Sumatera for agricultural development. International Peat Society.Symposium on Tropical Peat and Peatland for Development. Yogyakarta, 9-14 Februari 1987

Kementerian Lingkungan Hidup dan Kehutanan (KLHK). 2016. Pedoman Pemulihan Ekosistem Gambut.

Noor, M., 2001. Pertanian Lahan Gambut: Potensi dan Kendala. Penerbit Kanisius.

Rasyid, Fachmi. 2014. Permasalahan dan Dampak Kebakaran Hutan. Jurnal Lingkar Widyaiswara, Edisi 1, No. 4. Hal : 47 - 59

Rumajomi HB. 2006. Kebakaran hutan di Indonesia dan dampaknya terhadap kesehatan. Makalah pengantar Filsafah Sains, Program Pasca Sarjana. Bogor: Institut Pertanian Bogor.

Saharjo, B.H dan Syaufina, Lailan. Tanpa Tahun. Ekosistem Lahan Gambut Tropis. Jakarta: Cifor.

Soeriaatmadja, R. E. 1997. Dampak Kebakaran Hutan Serta Daya Tanggap Pengelolaan Lingkungan Hidup dan Sumberdaya Alam Terhadapnya. Prosiding Simposium : Dampak Kebakaran Hutan terhadap Sumberdaya Alam dan Lingkungan. Tanggal 16 Desember 1997 di Yogyakarta. Hal: 36 - 39.

Subagyo, H. 1998. Karakteristik bio-fisik lokasi pengembangan sistemusaha pertanian pasang surut, Sumatera Selatan. Pusat Penelitian Tanah dan Agroklimat, Bogor (Tidak dipublikasikan).

Tacconi, Luca. 2003. Kebakaran Hutan di Indonesia: Penyebab, Biaya, dan Implikasi Kebijakan. Jakarta: CIFOR. 
Undang-Undang Nomor 32 tahun 2009 tentang Perlindungan dan Pengelolaan Lingkungan Hidup. Vink, APA. 1975. Landuse Inadvancing Africulture Springer Verlag. New York Helderberg.

\section{LAMAN}

blh.jogjaprov.go.id. Diakses pada Selasa 17 Mei 2016 pukul 10.44 WIB.

blogs.itb.ac.id. Diakses pada Selasa, 17 Mei 2016 pukul 10.57 WIB.

eprints.ung.ac.id. Diakses pada Minggu, 22 Mei 2016 pukul 16.20 WIB.

news.detik.com. Diakses pada Minggu, 22 Mei 2016 pukul 16.35 WIB.

sains.kompas.com. Diakses pada Minggu, 22 Mei 2016 pukul 15.00 WIB.

www.bbc.com. Diakses pada Minggu, 22 Mei 2016 pukul 15.10 WIB.

www.litbang.pertanian.go.id. Diakses pada Minggu, 22 Mei 2016 pukul 16.50 WIB.

www.kompasiana.com. Diakses pada Minggu, 22 Mei 2016 pukul 16.23 WIB.

www.unisosdem.org. Diakses pada Minggu, 22 Mei 2016 pukul 20.07 WIB. 